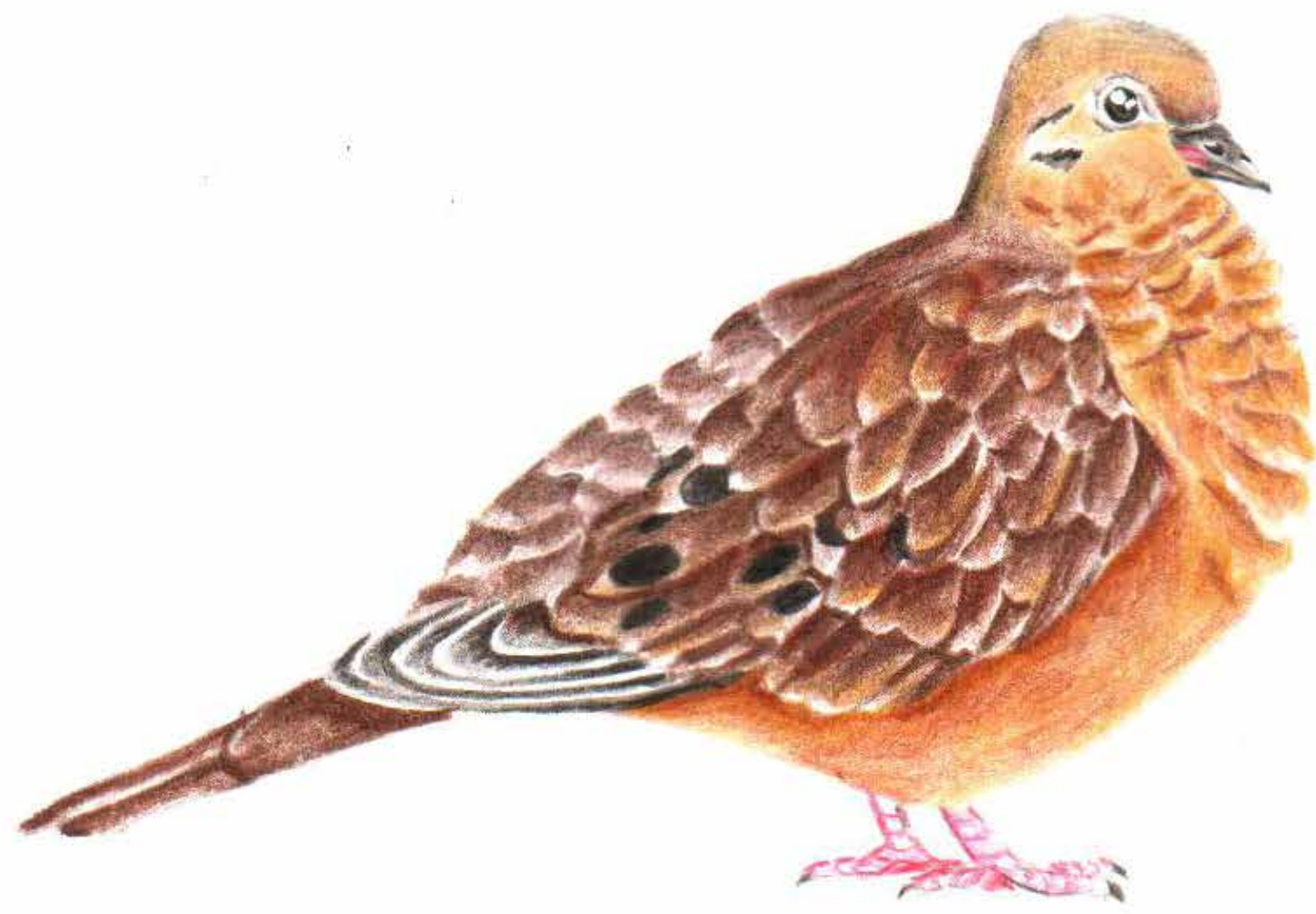

Jeny Andrea Fuentes Acevedo

Estudiante de Sexto Semestre de Licenciatura en Biología Universidad Pedagógica Nacional

Técnica: Lápices de colores 


\section{EL CHOCÓ EN IMÁGENES: UN RECORRIDO POR LA DIVERSIDAD BIOCULTURAL DEL MUNICIPIO DE BAHÍA SOLANO}

Fecha de recepción: 31 de marzo de 2014 Fecha de aprobación: 02 de junio de 2014
Germán Felipe Rodríguez Moreno ${ }^{1}$
"El verdadero viaje de descubrimiento consiste no en buscar nuevos paisajes, sino en tener nuevos ojos"

Marcel Proust

Presento algunos de los momentos captados desde el segundo semestre del año 2013 en el municipio de Bahía Solano, Pacífico Norte de Colombia. A partir de esta fecha, inicio un proceso de investigación colaborativa indagando acerca de las relaciones entre ecosistemas y culturas en esta región chocoana desde un enfoque educativo y de conservación biológica.

Uno de los elementos en los que seguramente pensamos cuando oímos hablar del Pacífico colombiano, es en la gran diversidad ecosistémica y de especies que se encuentra en esta región, sin embargo, comprender cabalmente la naturaleza requiere verla e interpretarla en términos de su contexto biofísico y cultural (Escobar A, 2010), y por supuesto, a partir de la inter-relacionalidad de dichos contextos. Bahía Solano es un territorio que sostiene el proyecto de vida de comunidades negras, indígenas y mestizas, poblaciones que interaccionan día a día con el imponente Océano Pacífico y las maravillosas e intrincadas complejidades del bosque tropical.
Las experiencias vividas allí deben ser narradas desde muchos ángulos, es por esto, que la fotografía se convierte en una herramienta de investigación que permite mostrar elementos de la cotidianidad que las palabras tanto orales como escritas no lo permiten. De esta forma, el licenciado en biología, en su rol como investigador, debe permanecer en una búsqueda constante de momentos y situaciones que por su historia, particularidad y belleza deban ser captadas por su lente.

En este sentido, presento una serie de imágenes de carácter etnográfico y paisajístico que con la ayuda de nuestro sistema sensorial nos llevarán en un recorrido reflexivo por el territorio solaneño y su cotidianidad, a continuación: el Chocó en Imágenes.

1 Estudiante de Licenciatura en Biología. Universidad Pedagógica Nacional. Grupo de Investigación en Enseñanza de la Biología y Diversidad Cultural. Correo Electrónico: gfrm90@gmail.com 


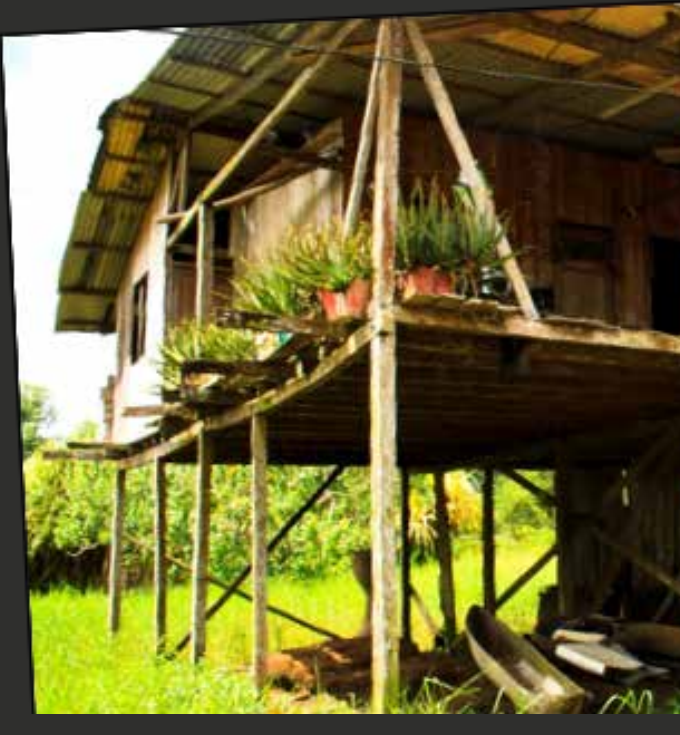

\section{Cultura anfibia en Bahía Solano}

Las prácticas cotidianas de las comunidades de la Bahía de Solano están profundamente influenciadas por el fenómeno de las mareas. En periodos de pleamar el agua aumenta su nivel de manera tal que se hace imprescindible el uso de lanchas o canoas para transportarse de un lugar a otro.

Es por esto que una buena parte de las viviendas solaneñas están construidas de forma elevada para evitar que el agua ingrese a sus viviendas.
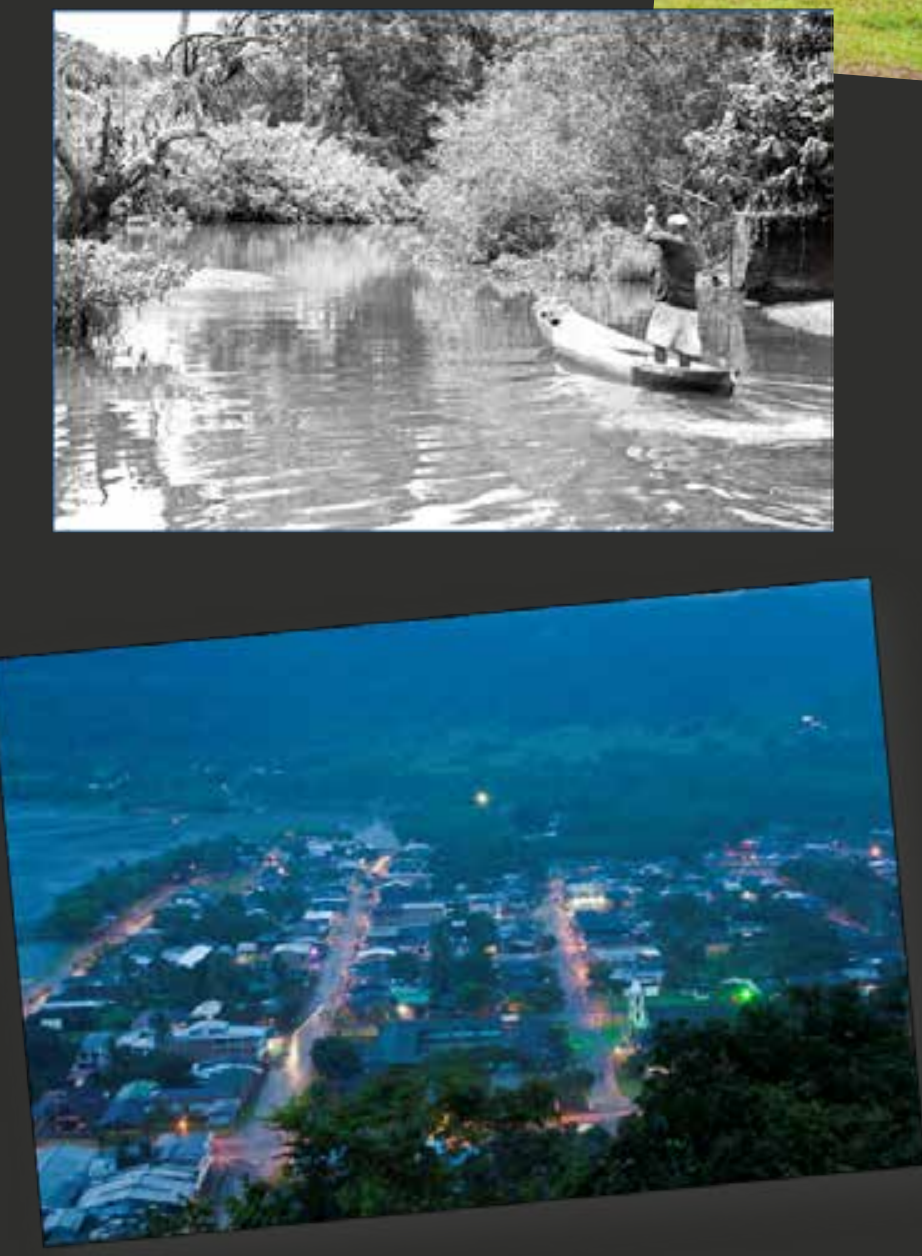

\section{Municipio diverso, oficios diversos}

Aunque Bahía Solano se caracteriza por ser un municipio con una profunda tradición pesquera, sus habitantes se dedican a múltiples oficios que les representan su forma de sustento.

En la fotografía puede observarse a un agricultor solaneño que se dirigía hacía su finca, en la cual mantiene sembrados de plátano, entre otras plantas, que generalmente son utilizadas para su consumo dentro del municipio.

\section{Cae la noche en Bahía Solano}

Ante el asombro de pobladores y estudiantes, aquel día, en compañía de mi compañera de práctica y de Davinsson, un ingeniero forestal solaneño, subimos a La Loma de la Virgen, un lugar místico que ofrece una gran vista que tan solo nuestros ojos pueden captar en detalle. Aquel día, ni espantos, ni serpientes venenosas evitaron el deleite de ver la caída de la noche, acompañado del sonido de miles de insectos y de varios mamíferos alados que salían en búsqueda de alimento. 


\section{La Loma de la Virgen}

Las comunidades negras, mestizas e incluso indigenas tienen tradiciones profundamente ligadas al aspecto religioso, principalmente católico. En uno de los puntos más altos del municipio de Bahía Solano, encontramos una imagen de la Virgen del Carmen, razón por la cual este sitio recibe tal nombre.
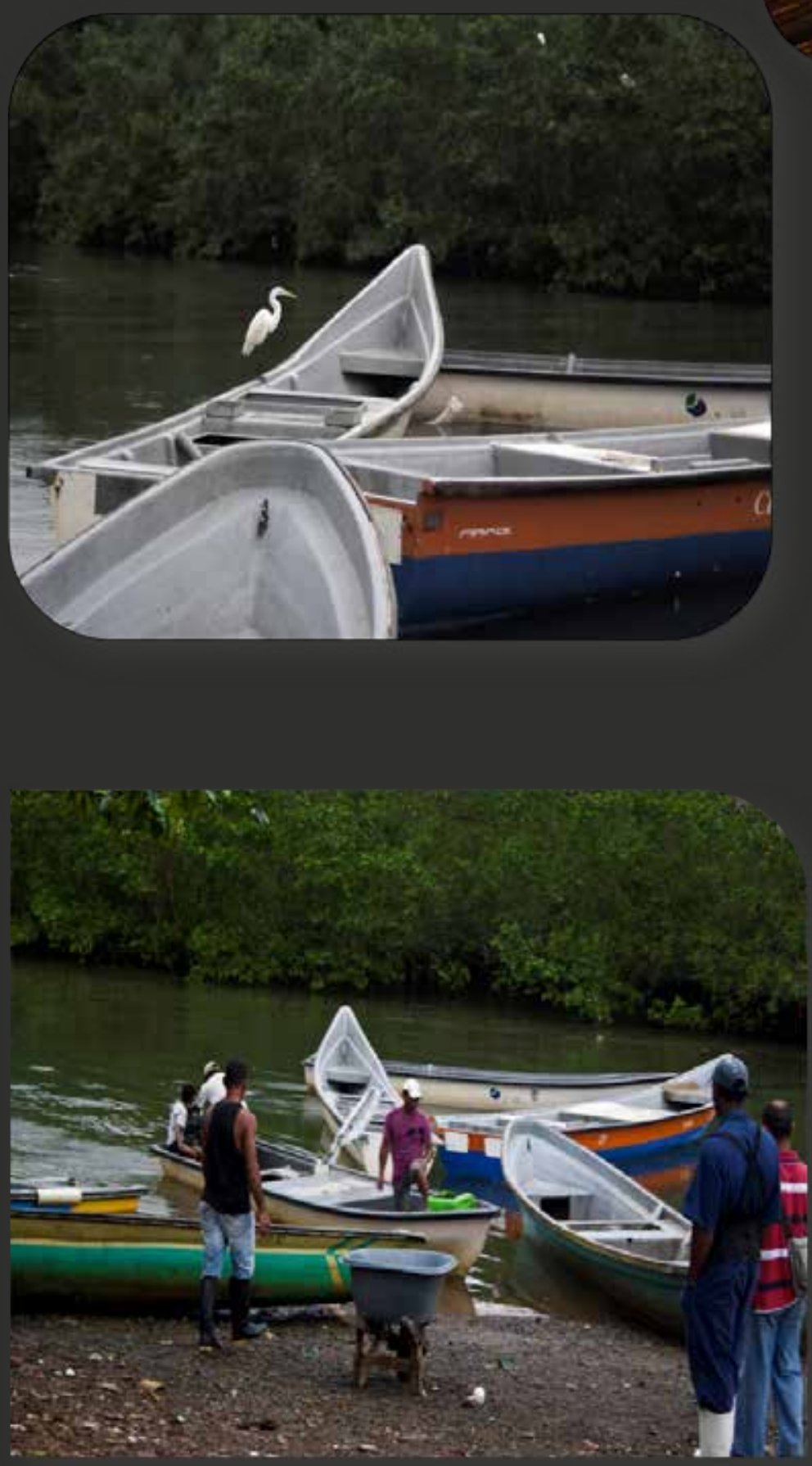

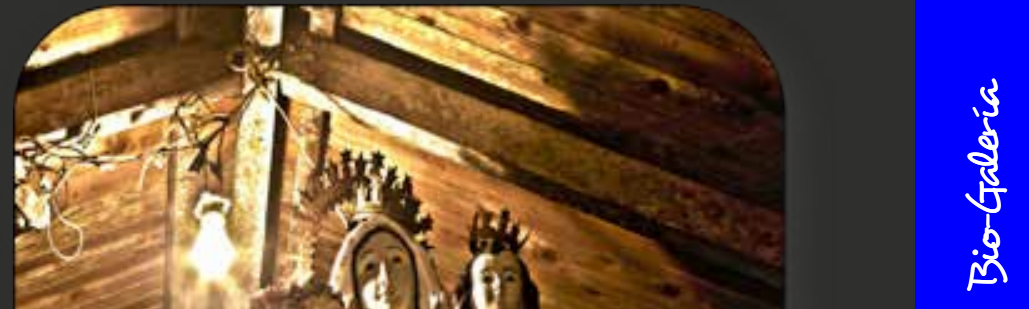

Río Jella-rumbo al Océano Pacífico-

A pocos metros de este lugar, se presenta la confluencia entre el Río Jella y el Océano Pacífico, este río es utilizado por los pescadores artesanales que salen a hacer sus faenas al océano aprovechando la pleamar. De fondo podemos ver una garza blanca (Casmerodius albus), posando sobre una lancha.

\section{Jornada de pesca}

Al inicio de la alborada, comienzan a llegar los pescadores que habían estado en las horas de la noche en las aguas del Océano Pacífico; muchos peligros acechan al pescador solaneño, sin embargo, éste es su estilo de vida, la conexión existente entre él y el océano es inseparable. 


\section{El gran pez rojo}

La diversidad de la ictiofauna en el Pacífico es impresionante. Los pescadores capturan una gran variedad de peces con métodos artesanales, con lo cual ayudan a asegurar la soberanía alimentaria de su pueblo; en este caso, habían capturado un enorme pez, que me dejó sorprendido la primera vez que le vi, se trataba de un pargo muelón, (Lutjanus jordani), un feroz carnívoro que habita no muy lejos de las costas.
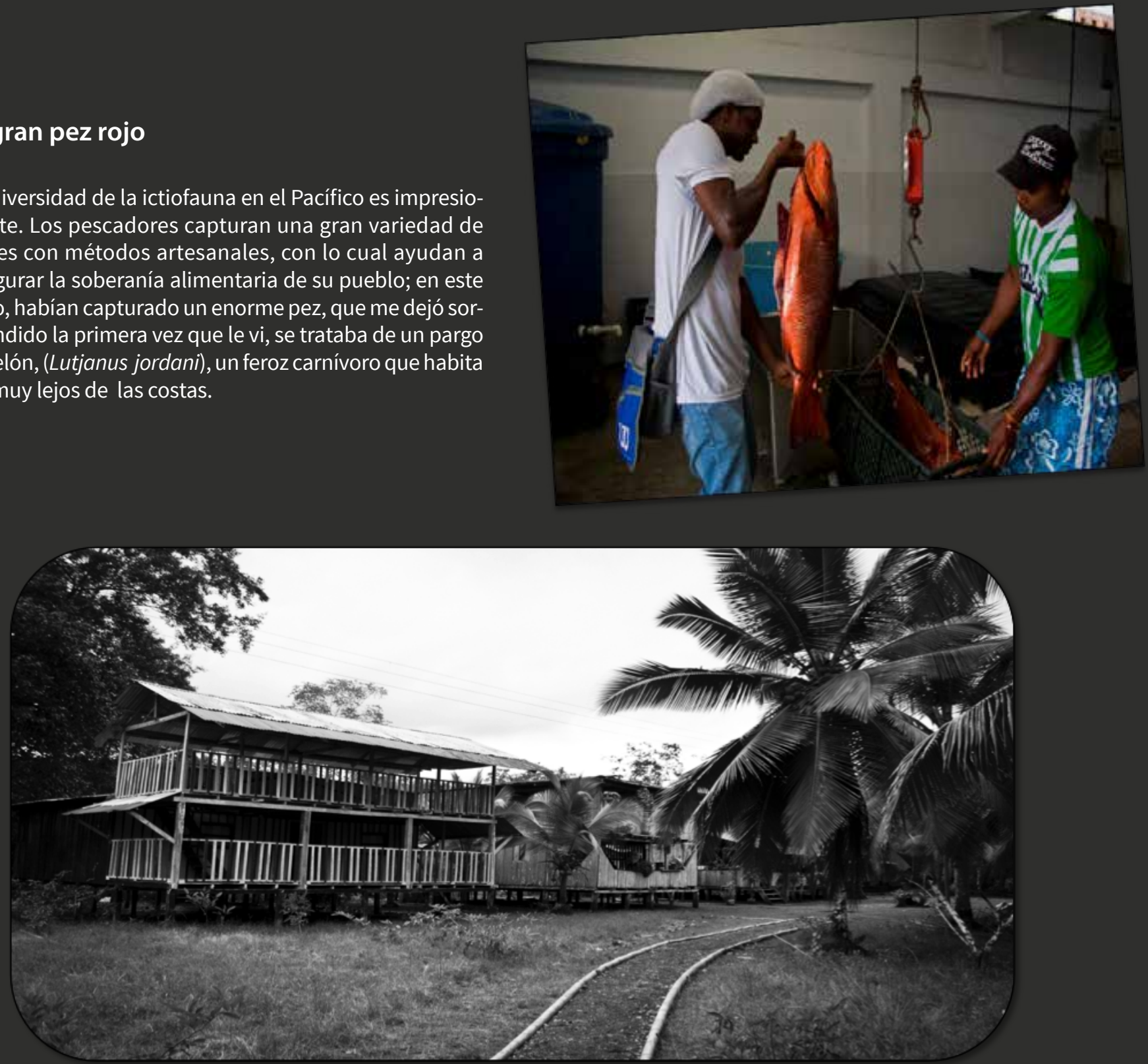

\section{Corregimiento de Mecana}

Mecana es uno de los corregimientos del municipio de Bahía Solano, unos cuantos pasos en este territorio nos bastan para ver observar viviendas abandonadas, ya que muchos de sus habitantes tradicionales han migrado hacia la cabecera municipal. Sin embargo, la compañía del océano, de las aves playeras y del ecosistema de manglar, hacen de este lugar un ambiente místico, digno de ser recorrido.

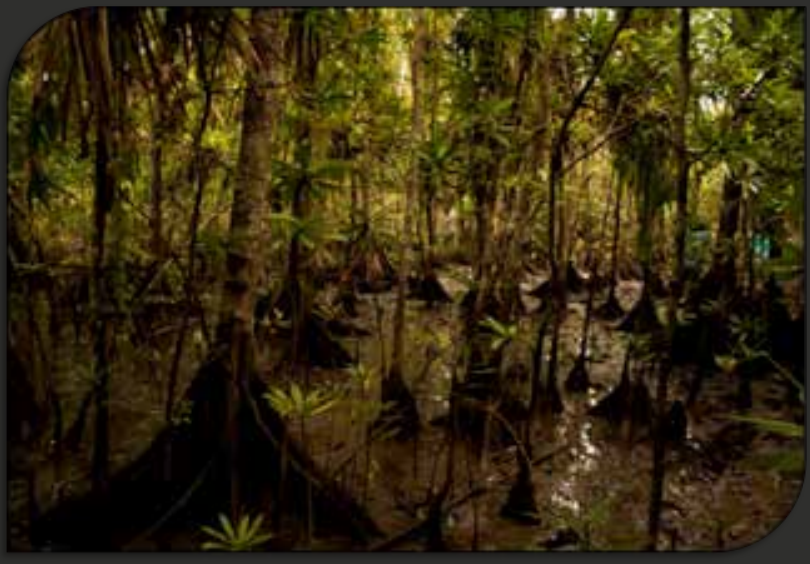

\section{Caminando por el manglar}

Al caminar por el manglar de Mecana debemos tratar de agudizar nuestros sentidos al máximo, un buen observador podrá captar las complejas dinámicas de este ecosistema, gran cantidad de plantas aéreas, moluscos y artrópodos resaltan en este ambiente. Es interesante analizar cómo Pelliciera rhizophorae o mangle piñuelo se destaca como una de las especies más abundantes de la zona. 


\section{Chupa-Chupa}

En el recorrido por la zona de manglar, se encuentran varias de estas semillas posando sobre el mangle piñuelo, reciben el nombre de propágulos y las caracteriza su forma acorazonada. Los niños de la región le llaman "Chupa-Chupa", ya que en ocasiones lo utilizan como alimento extrayendo un líquido ligeramente dulce que se encuentra en su interior.
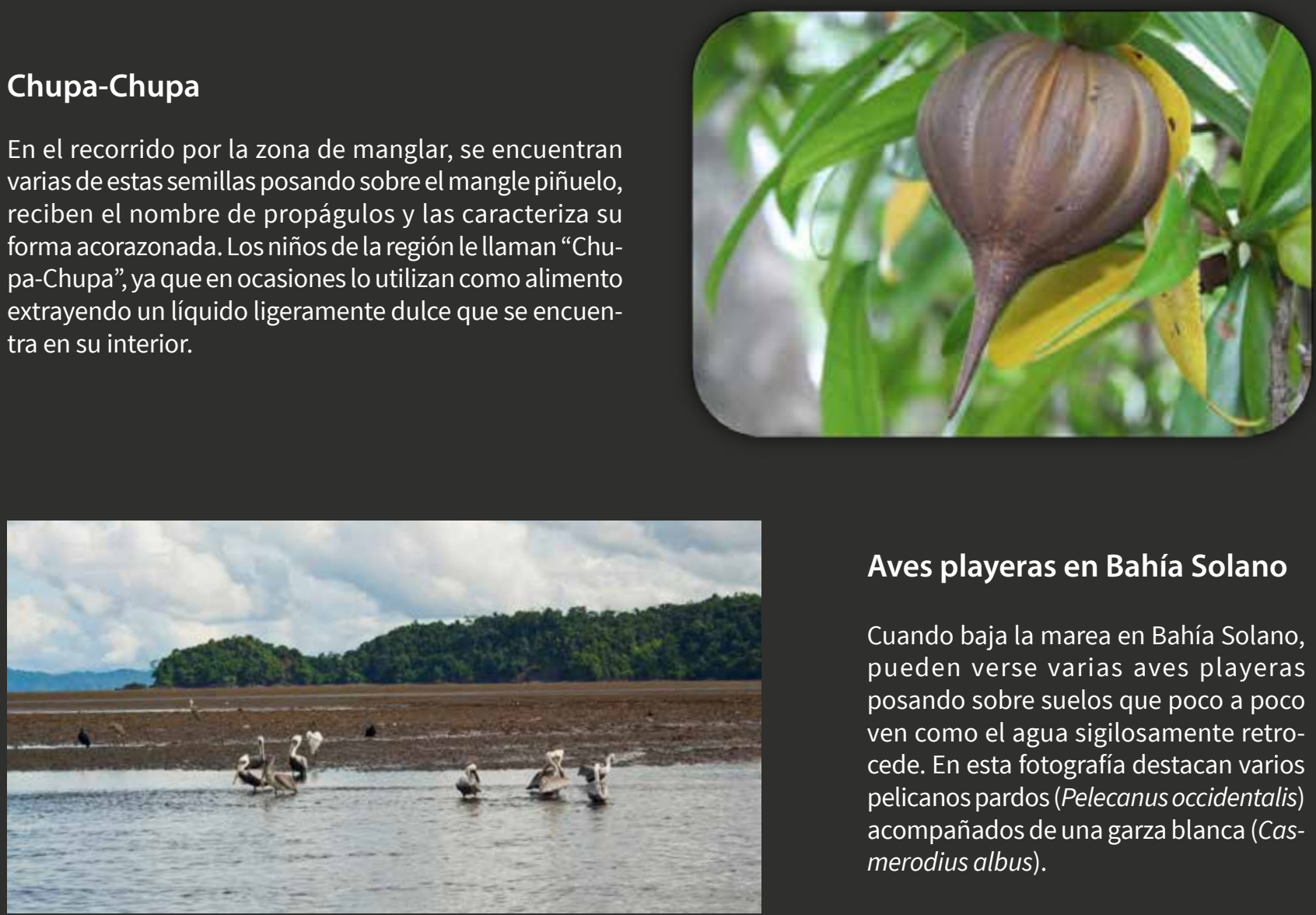

\section{Aves playeras en Bahía Solano}

Cuando baja la marea en Bahía Solano, pueden verse varias aves playeras posando sobre suelos que poco a poco ven como el agua sigilosamente retrocede. En esta fotografía destacan varios pelicanos pardos (Pelecanus occidentalis) acompañados de una garza blanca (Casmerodius albus).

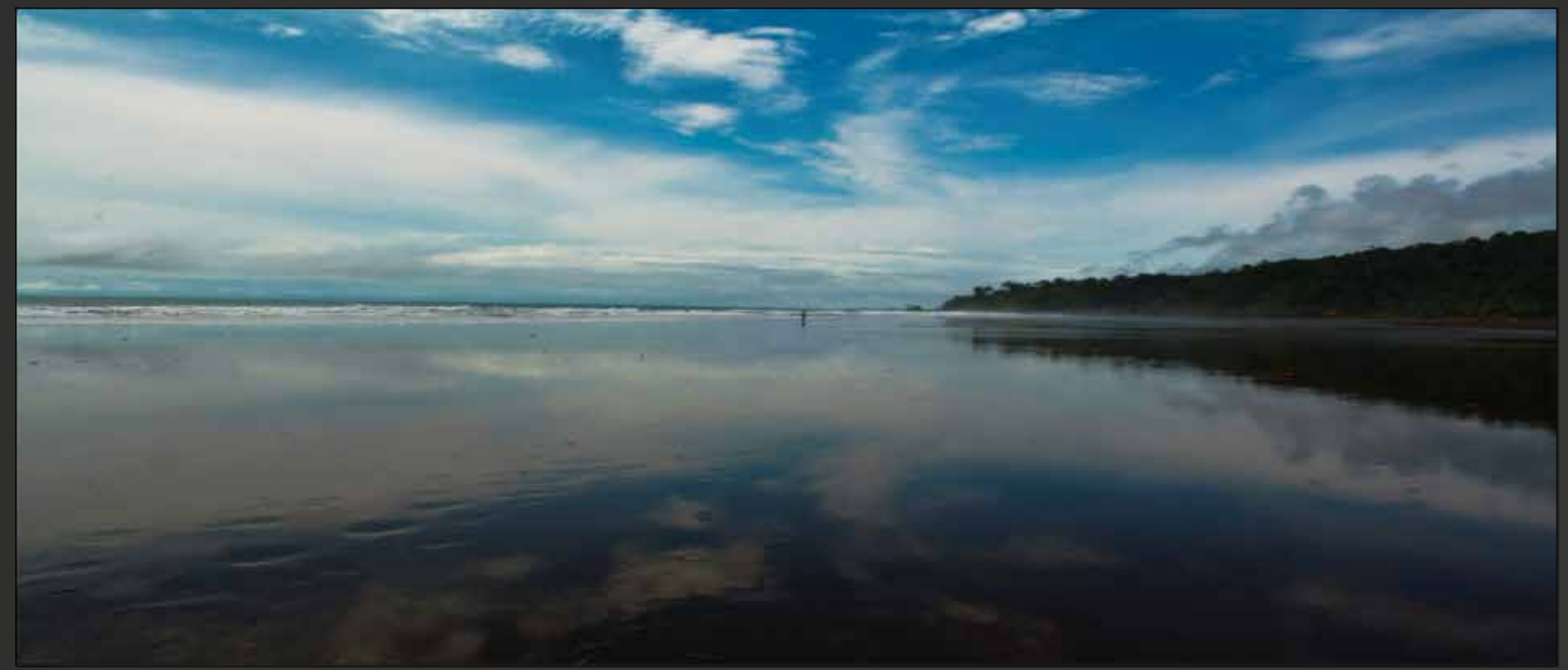

\section{El cielo y el océano se confunden en el horizonte}

Les presento otro de los corregimientos de Bahía Solano (El Valle), quizás, desde mi punto de vista, el más encantador. Aquel día, caminando sobre la playa en periodo de bajamar y mientras un lugareño se perdía en el horizonte, pude captar el reflejo de un cielo reluciente de azul y blanco y de una porción del bosque chocoano, en el suelo humedecido de la playa. Por la majestuosidad del paisaje mismo y de la simetría lograda en el encuadre, sin duda, la considero una de mis fotografías favoritas. 


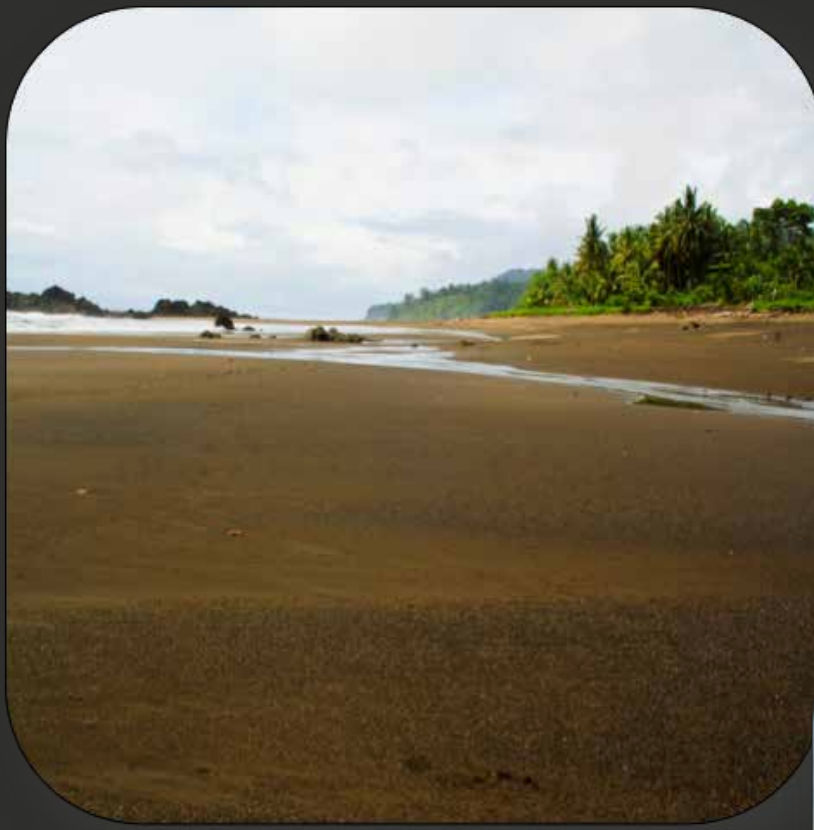

\section{Fin de la travesía}

Camines por donde camines, encontrarás que ríos y quebradas confluyen en múltiples puntos con las aguas del Océano Pacífico, terminando así, un largo viaje por tierras continentales.

\section{Representantes de la vieja tradición}

La pesquería en el municipio de Bahía Solano se ha transformado a través del tiempo; cuen-

tan los abuelos que ellos salían a pescar "a canalete", es decir, en estas canoas hechas de madera que a mi paso por la zona, se encontraban abandonadas a la orilla de la playa en el corregimiento del Valle.
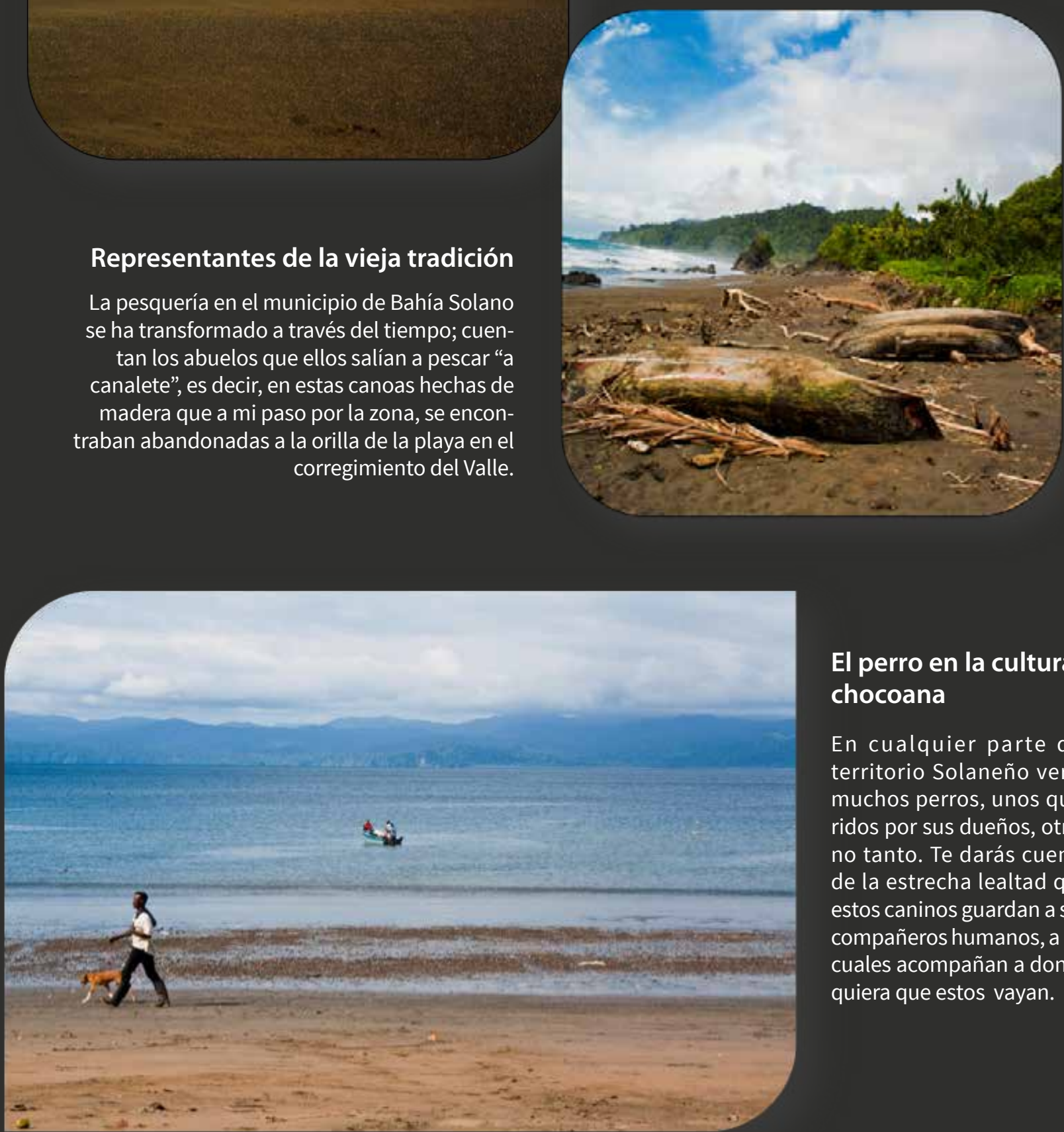

\section{El perro en la cultura} chocoana

En cualquier parte del territorio Solaneño verás muchos perros, unos queridos por sus dueños, otros no tanto. Te darás cuenta de la estrecha lealtad que estos caninos guardan a sus compañeros humanos, a los cuales acompañan a donde quiera que estos vayan. 


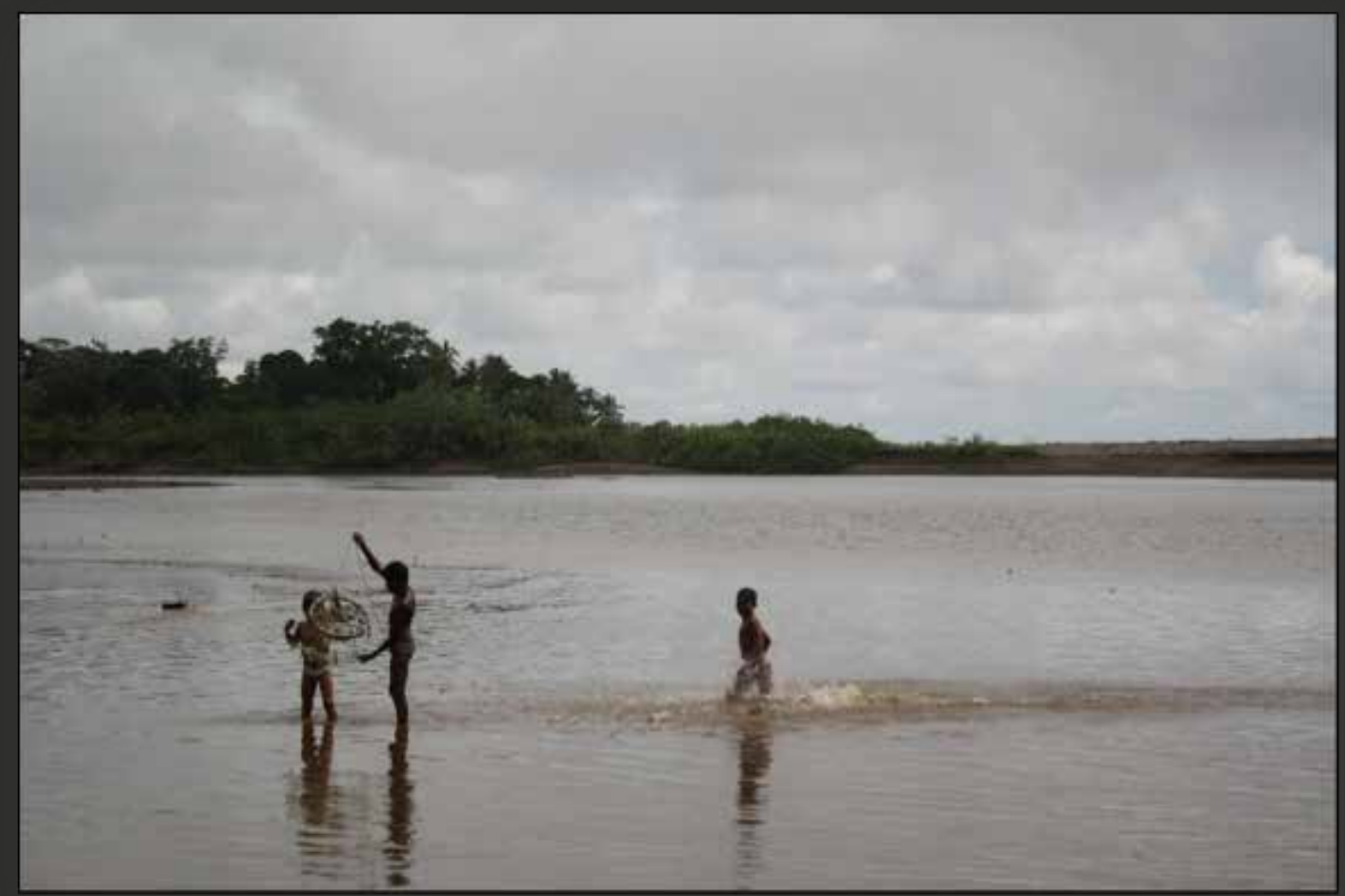

\section{Los niños y la pesca}

Pescar es una de las actividades preferidas de los niños del municipio, no es para menos, muchos de ellos mantienen una relación dialéctica con el océano y con los ríos, al punto de ser inquebrantable. En esta ocasión, niños afros e indígenas, se encontraban buscando jaibas (Callinectes sapidus) a orillas del Río Valle.

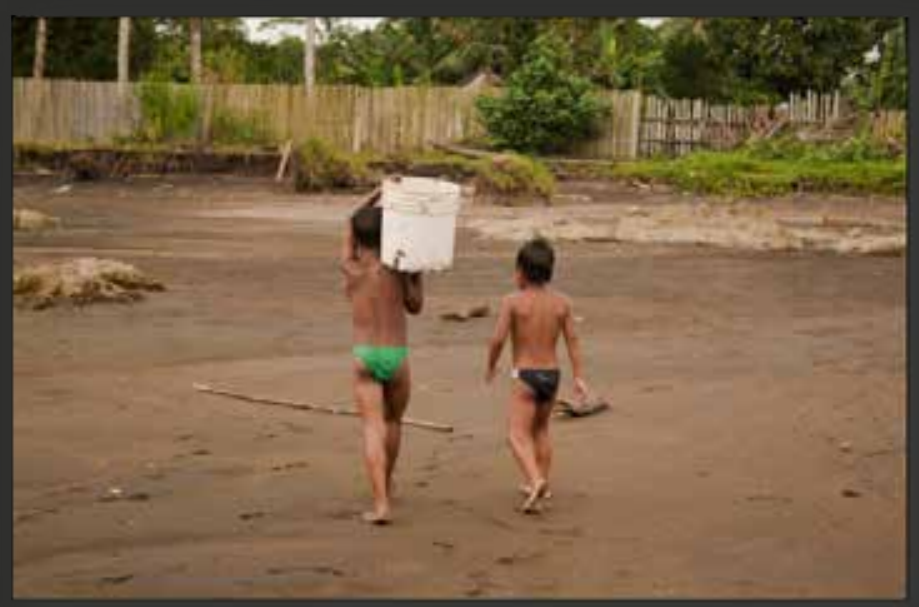

\section{Labor cumplida}

Luego de la jornada de pesca, los niños regresan a sus casas con varias de las jaibas atrapadas. Vale la pena resaltar que estos crustáceos azules hacen parte de la gastronomía de la región.

\section{Paraíso natural}

Desde el primer momento en que se ponen los pies sobre el territorio sola-

neño, debes comenzar a percibiry observar el ambiente con otros ojos, solo así podrás disfrutar cabalmente de esta mística región.

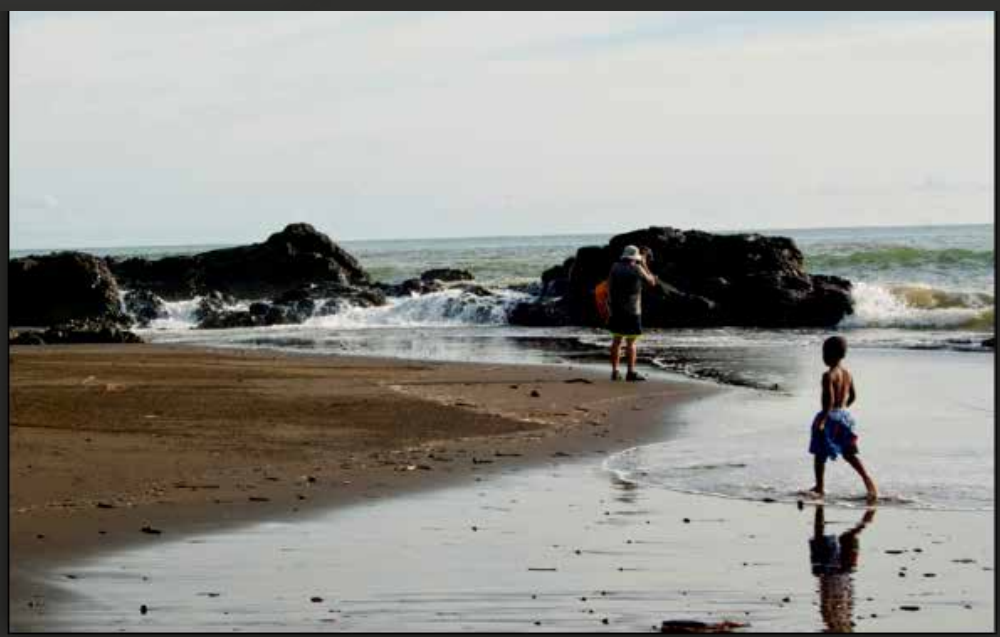




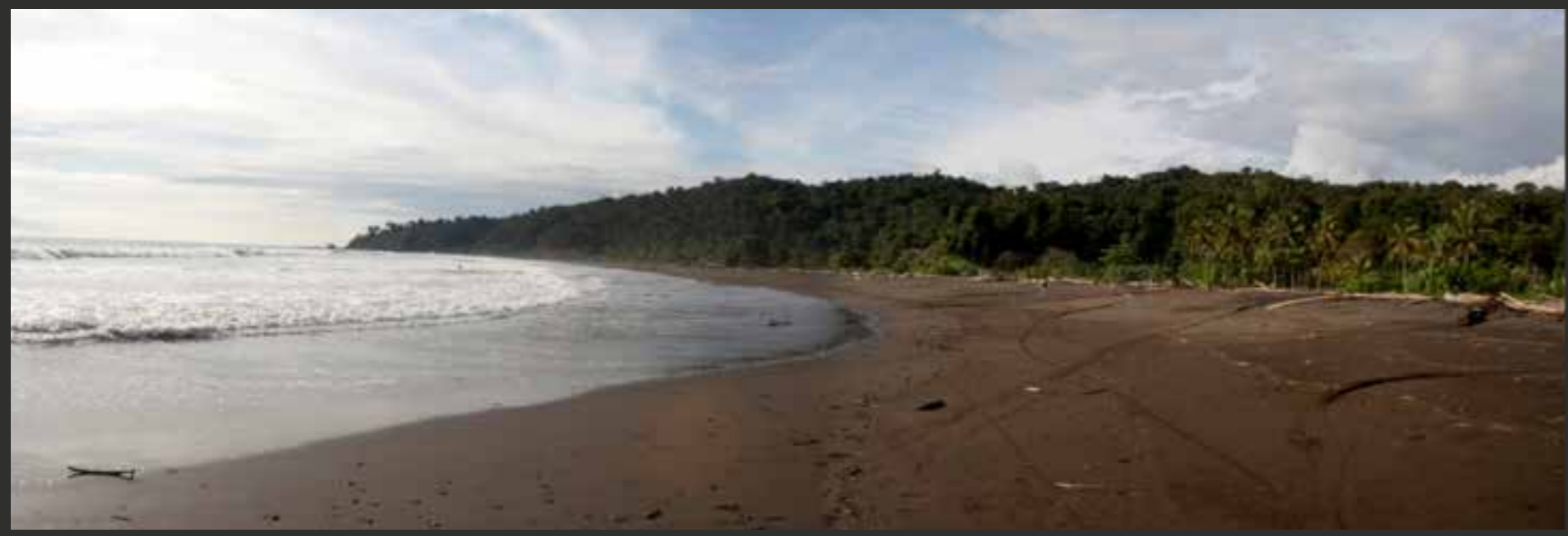

\section{Playa El Almejal}

Ubicada en el corregimiento del Valle, es una de las playas más visitadas por su incomparable majestuosidad, sin embargo, las intensas corrientes marinas en esta zona hacen que visitantes y lugareños le guarden mucho respeto.

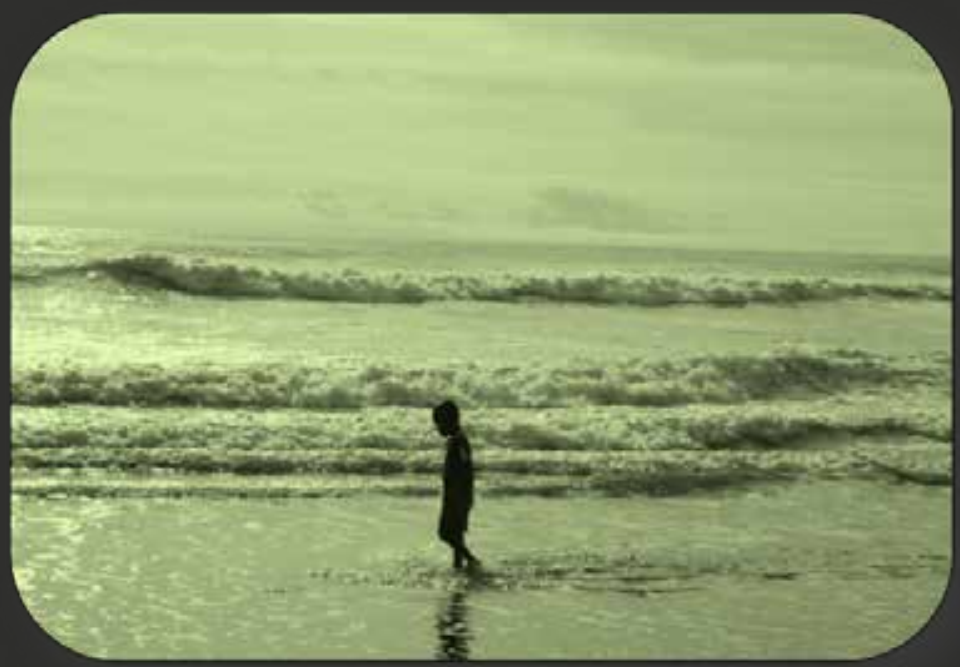

\section{Caminante solitario}

En el marco del intenso oleaje que caracteriza al corregimiento del Valle, un niño de una comunidad local camina solitario mientras las olas chocan incesantemente contra la costa.

\section{¡Yo quiero ser futbolista!}

Si preguntas a un niño de la región, sobre lo que quiere ser cuando sea grande, es probable que te responda que quiere dedicar su vida a practicar el futbol. Es esperanzador ver la forma y la dedicación con la que día a día entrenan para cumplir sus sueños.

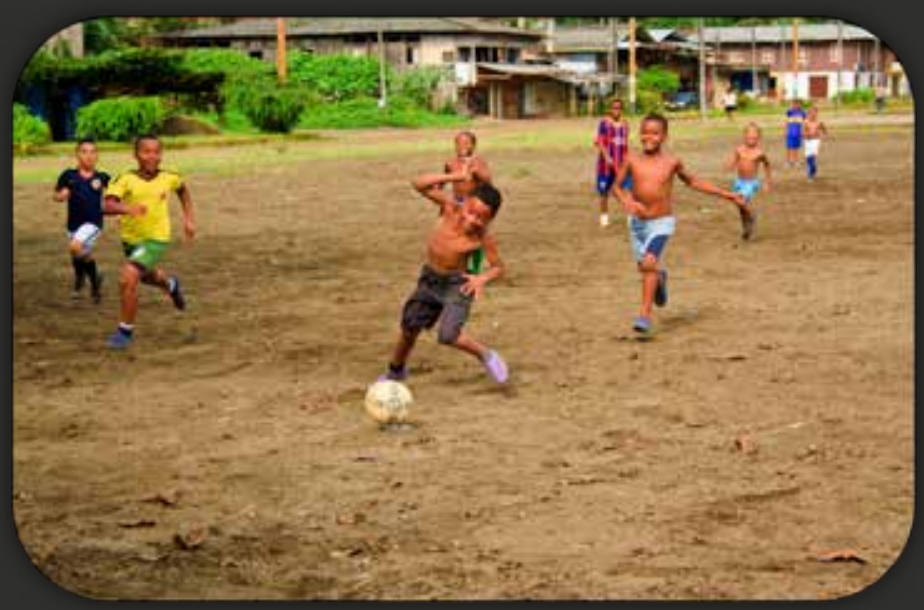




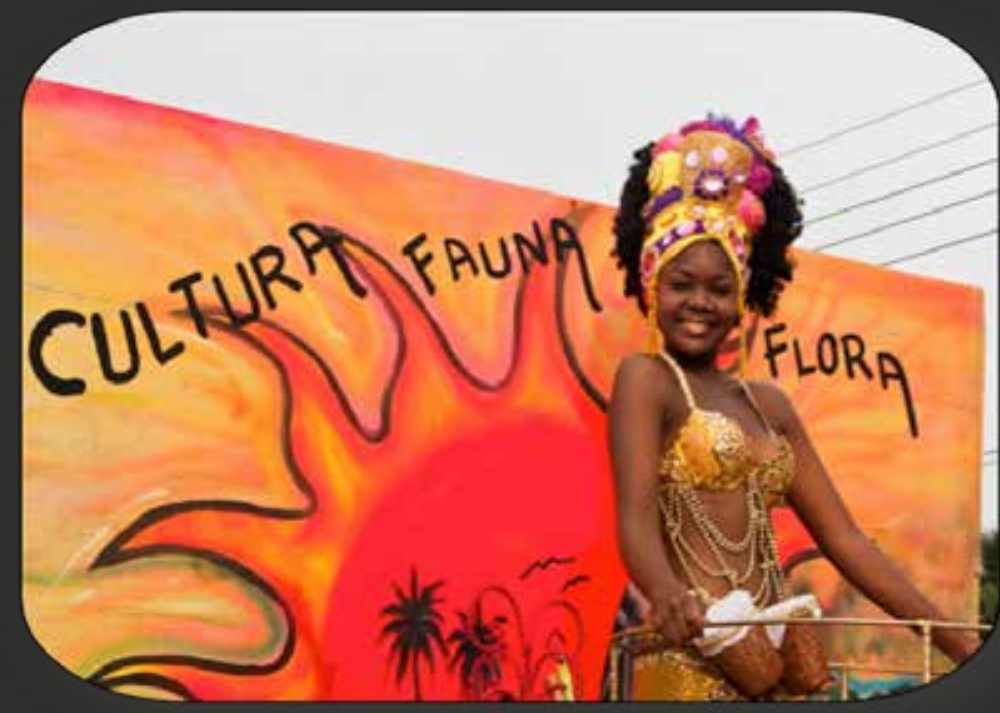

Reinado escolar

Rosa y Yussy, están listas para participar en el reinado escolar de la escuela primaria, que premiará los mejores vestidos hechos a partir de materiales reciclables.

\section{"El Bunde"}

Niños y niñas disfrutan de este baile típico de la región, mientras recorren calle por calle su municipio, convocando a los solaneños a unirse a las celebraciones.
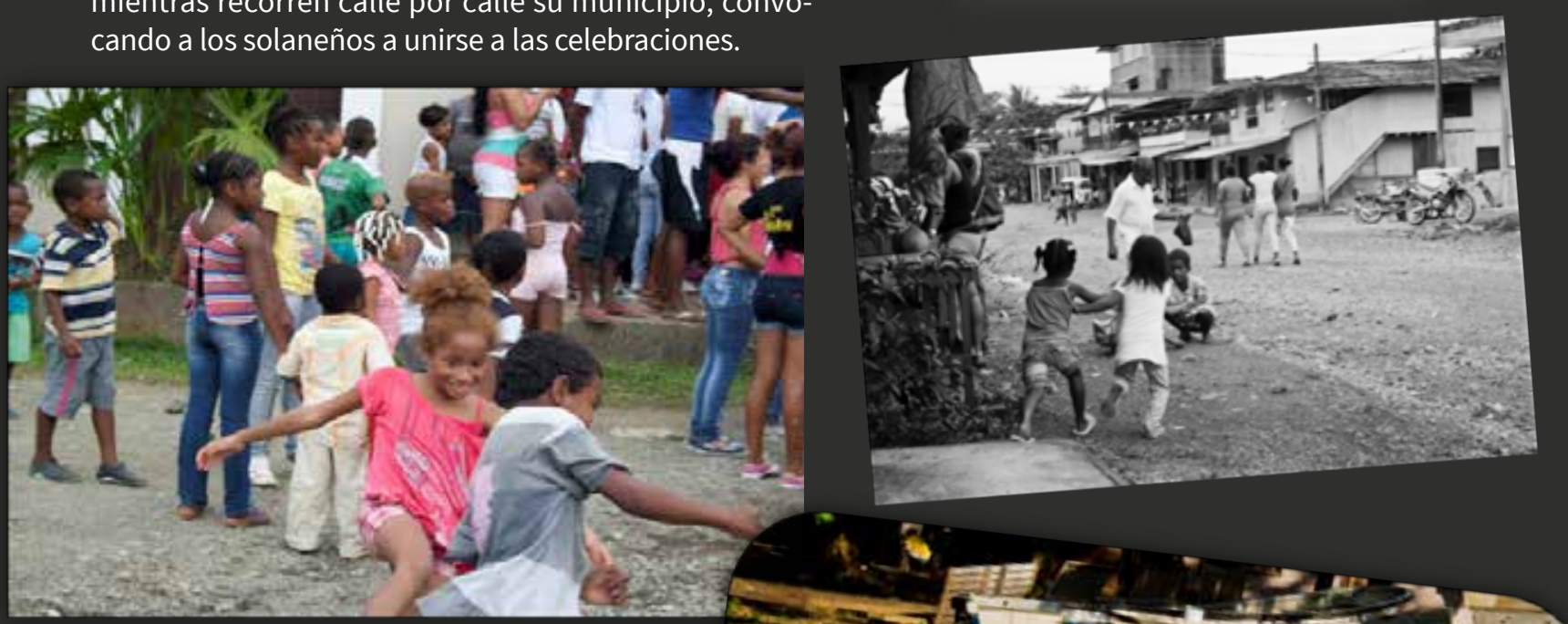

(4) 2

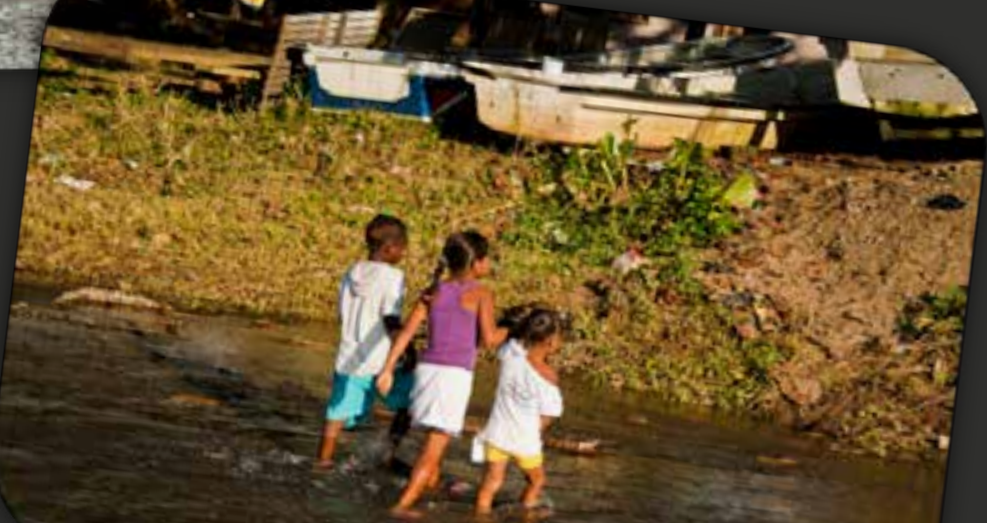
región. En el desfile de carrozas, esta candidata intentaba reflejar la diversidad biológica y cultural de su municipio.

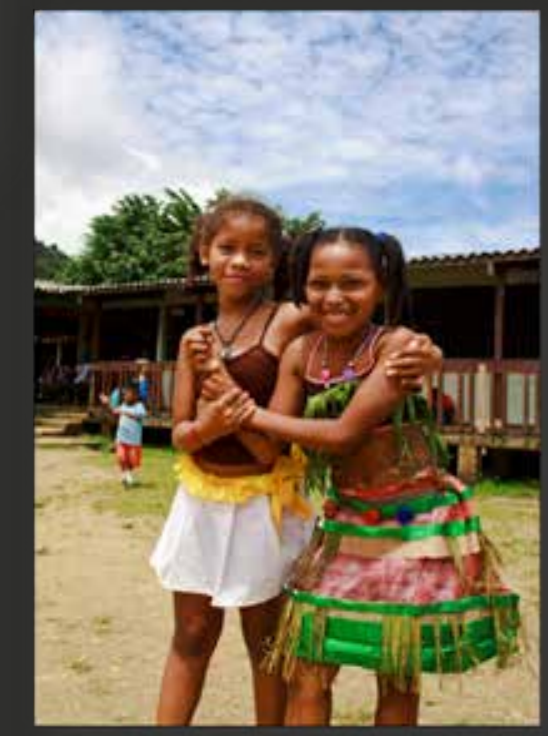

\section{Bahía Solano y su diversidad cultural}

Son fácilmente evidenciables los choques que se presentan entre los distintos grupos culturales que coexisten en la región (mestizos, indígenas y afrodescendientes). Sin embargo, una gran parte de ellos dejan a un lado sus diferencias raciales y establecen lazos de amistad y camaradería bastante interesantes, dándonos un grandioso ejemplo.

En el marco del Festival de la Bahía, varias niñas se preparan para participar del reinado que premia a la mujer más hermosa de la 


\section{Juegos del mar}

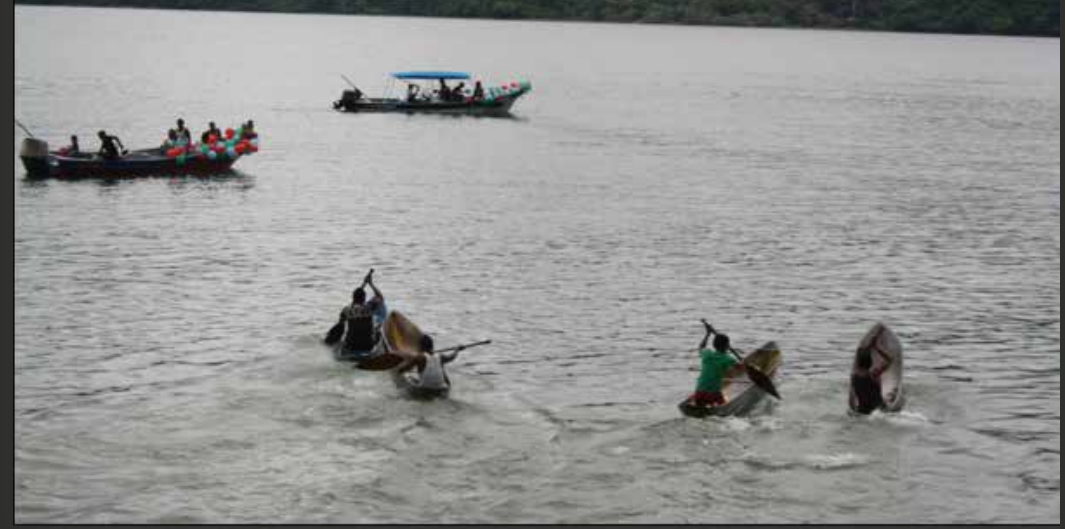

Reconociendo ese vínculo inquebrantable entre los solaneños y el océano, la Institución Educativa Luis López de Mesa de Bahía Solano Chocó, organiza anualmente en el marco de su semana cultural, una serie de juegos en los que maestros y estudiantes compiten para demostrar sus habilidades en la marinería.

\section{La lluvia en la escuela}

El Pacífico es reconocido por sus altos niveles de precipitación. Con frecuencia, la lluvia aparece y acompaña con su sonido el desarrollo de la jornada escolar, hace parte del contexto, incluso llegas a extrañarla cuando por diver-

sas razones de índole climático, esta tarda más de un día en volver a hacerse presente.

\section{La lluvia despide la jornada escolar}

El cielo se tornó gris y oscuro. Justo antes de terminar la semana escolar, las nubes no resistieron más el peso que acarreaban y dejaron caer sobre Ciudad Mutis, cientos y cientos de gotas que acompañaron por horas el pai-
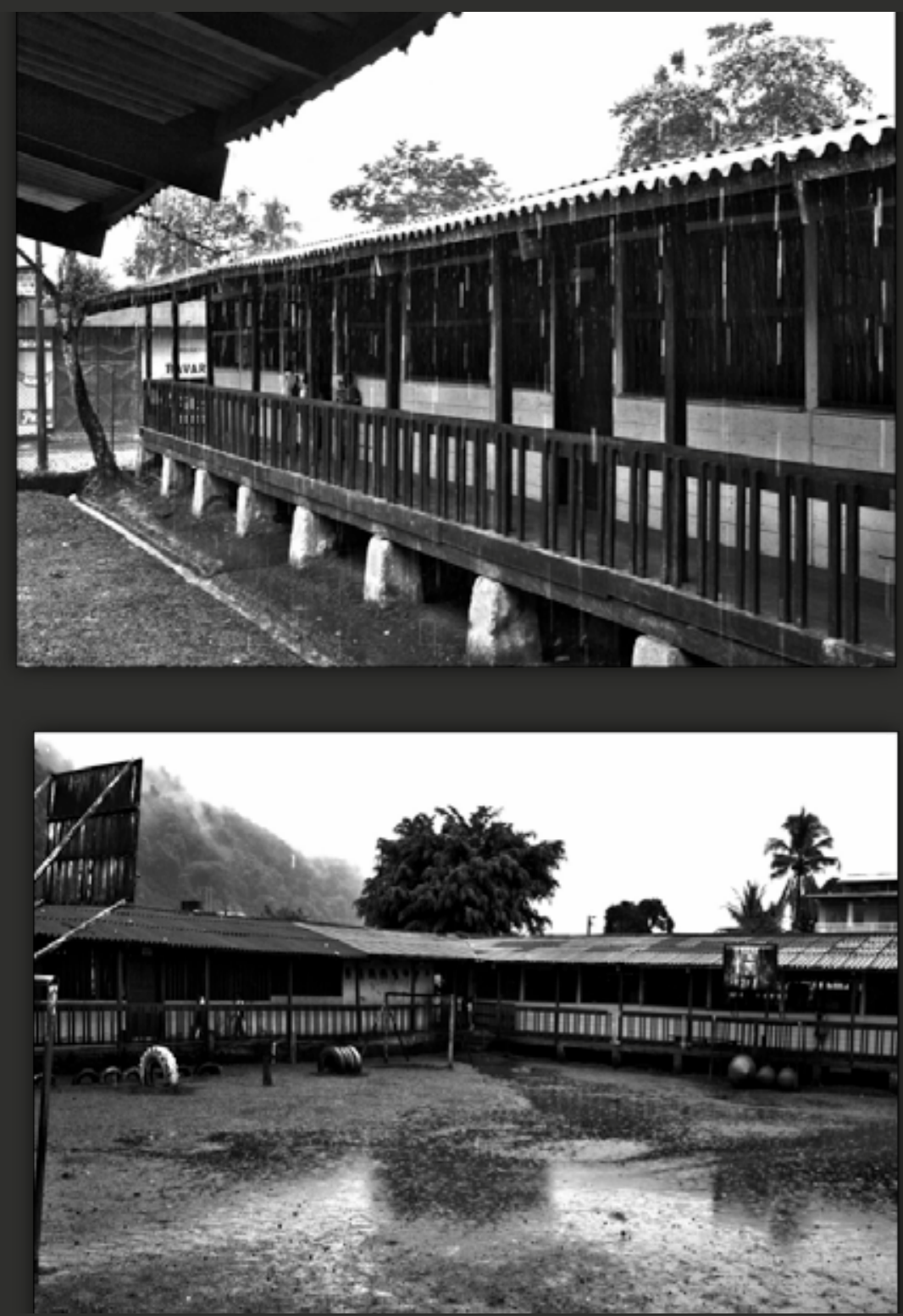


\section{Lo esencial es invisible a los ojos}

Una compañera al referirse a los retratos que pude captar durante mi estadía en Bahía Solano, me dijo que era impresionante todo lo que una imagen podía transmitir y generar en las personas; es así que para las imágenes que verán a continuación, omitílas palabras que podrían haberlas descrito para permitirles liberar su imaginación, agudizar sus sentidos y apreciar desde su perspectiva las miradas de esperanza que transmiten los rostros de estos niños solaneños.
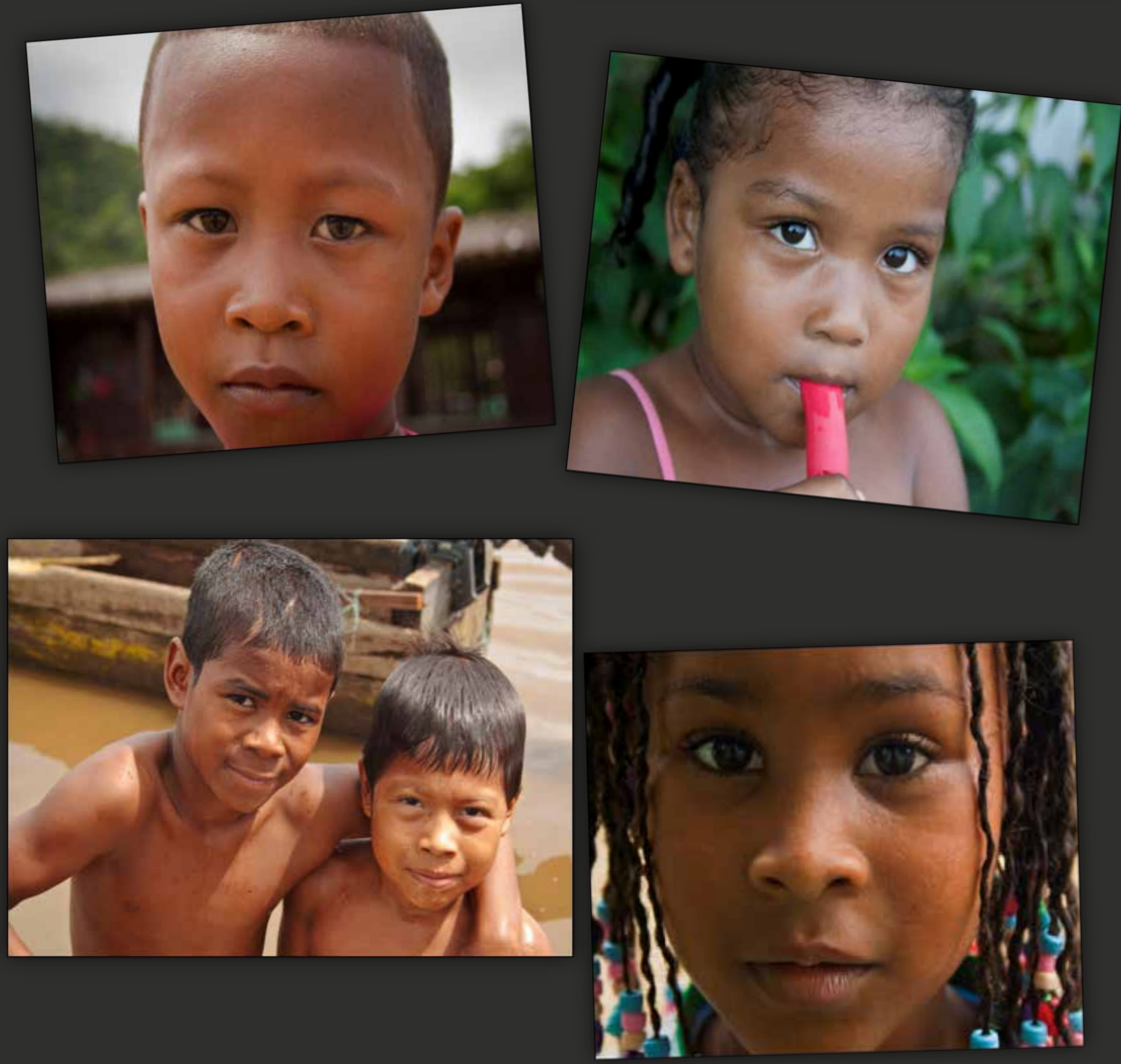

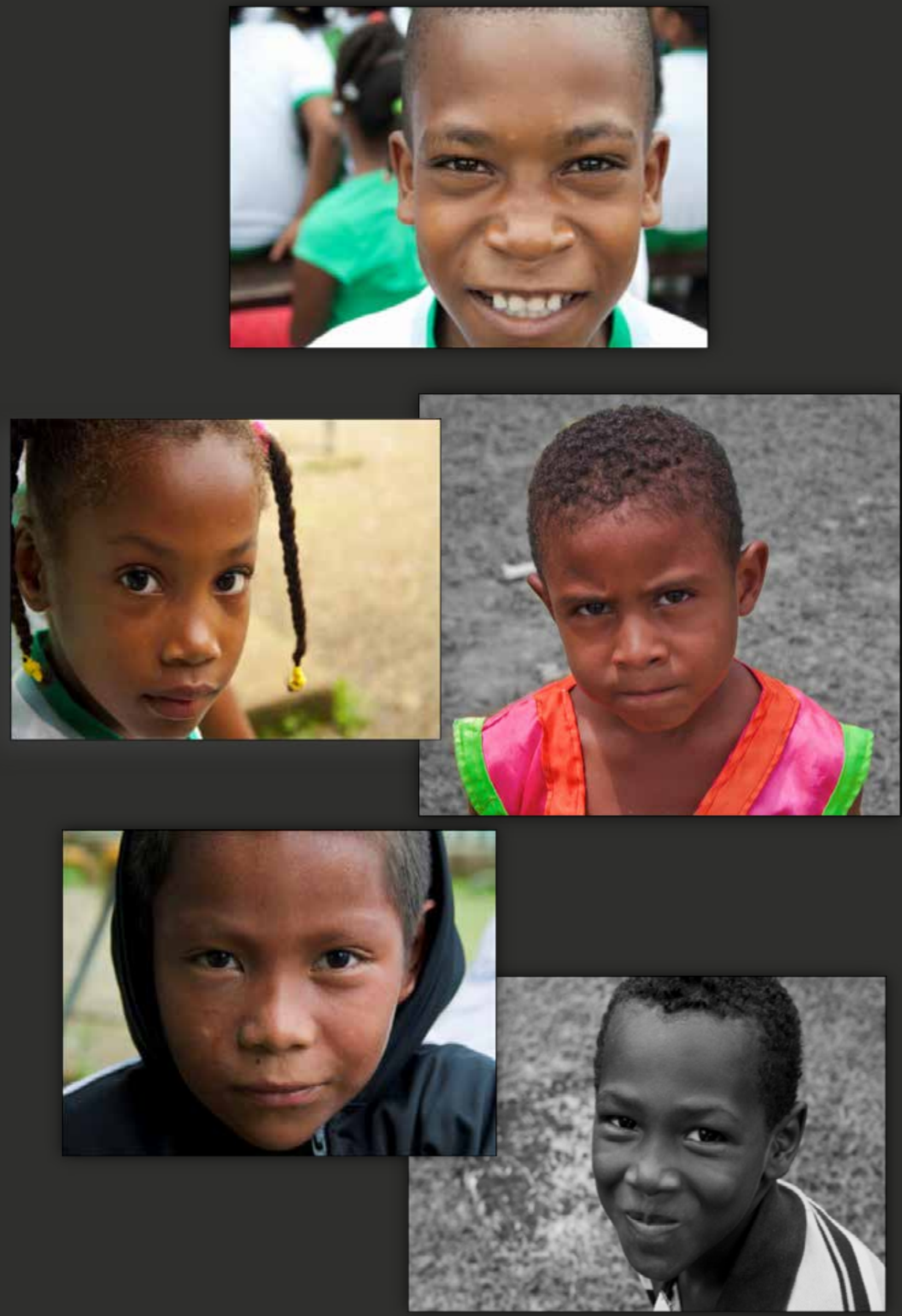


\section{Viaje hacia la inmensidad}

Poco a poco y moviéndose en la dirección de la corriente del Río Valle, los lancheros se dirigen hacia las aguas del Océano Pacífico, en donde tendrán que enfrentar fuertes vicisitudes. El intenso oleaje del océano en el corregimiento de El Valle, pone un poco de peligro sobre la labor de los pescadores, no deja de ser impresionante observar cómo las altas olas elevan e inclinan las lanchas llevándolas a una posición extrema, al filo de voltearse.

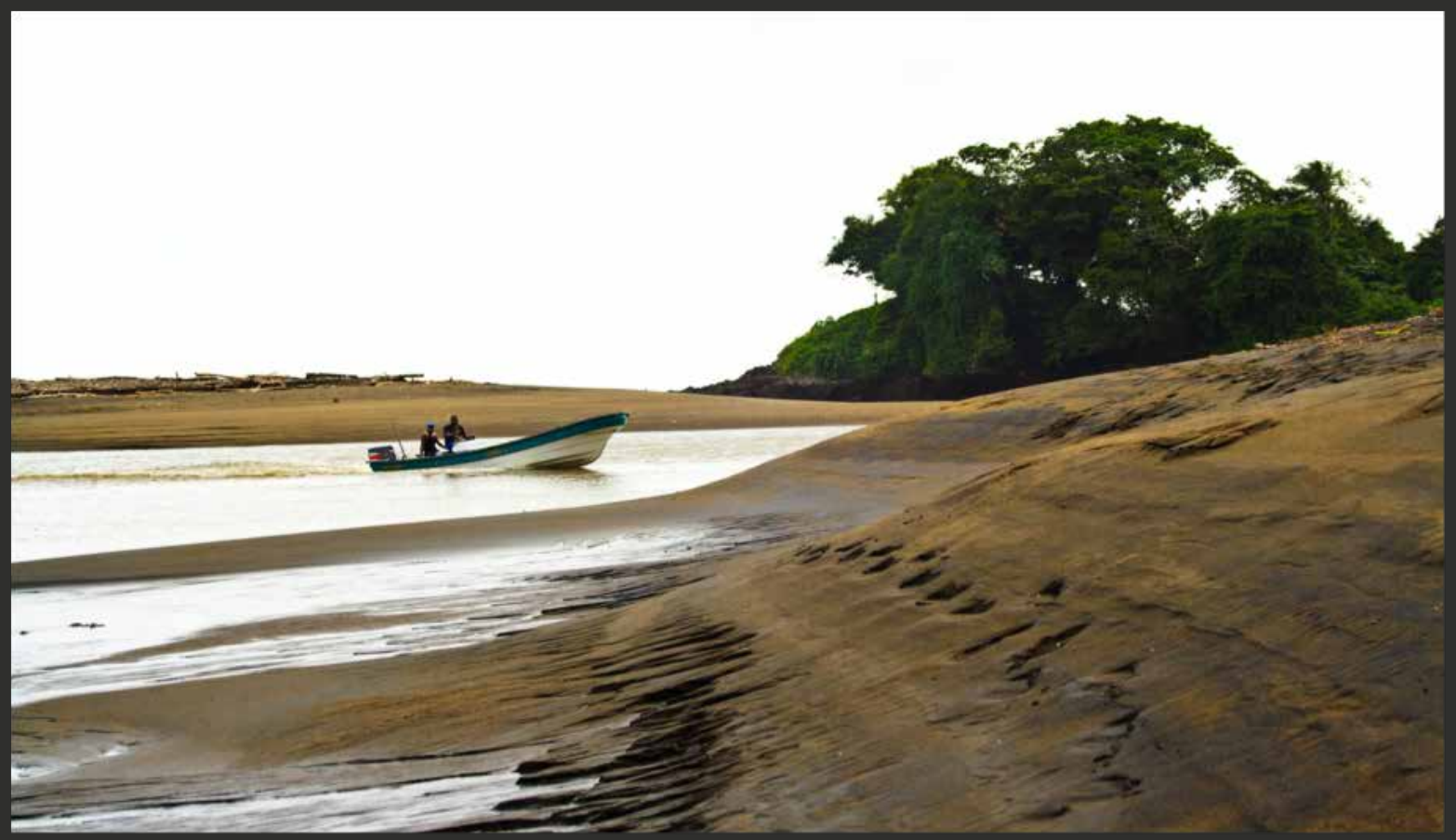

\section{Agradecimientos}

Aquel ejercicio de ver más allá de lo común, se va fortaleciendo en la interacción con otras formas y sistemas de pensamiento. Por esta razón, no puedo dejar de agradecer a los solaneños, ya que a partir del diálogo y la interacción con ellos, pude ir construyendo aprendizajes y evidenciando dinámicas del municipio que de otra forma me hubiera sido imposible.

Por ultimo quisiera agradecer al Departamento de Biología de la Universidad Pedagógica Nacional y particularmente a la Línea de Investigación Configuración de los Conocimientos acerca de lo Vivo y de la Vida por haber acompañado este proceso de investigación colaborativa en el Pacífico Norte de Colombia que espero continúe por muchos años más.

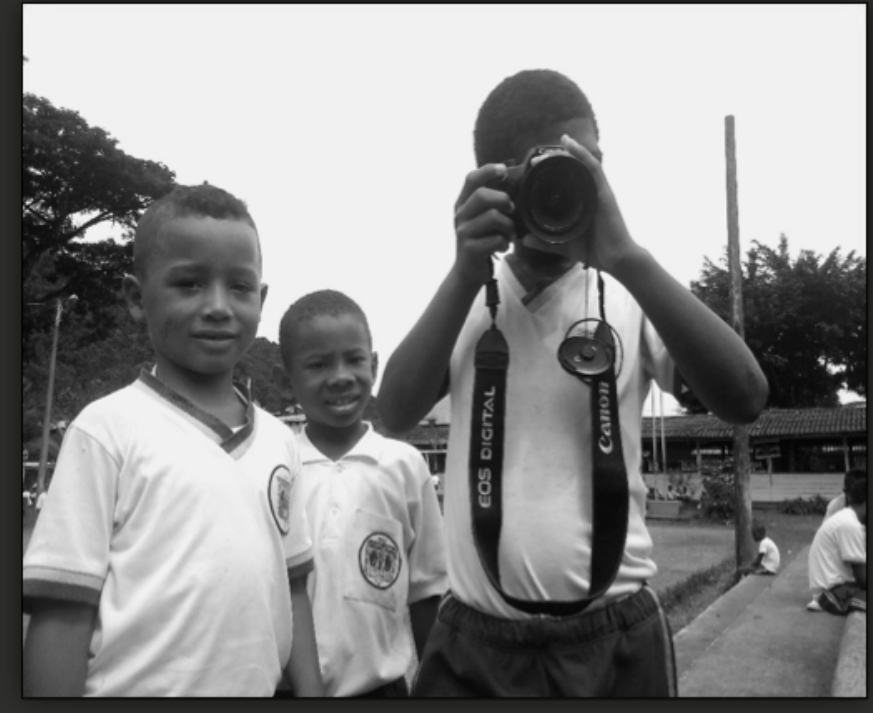

\section{Bibliografía}

Escobar, A. (2010). Territorios de diferencia: Lugar, movimientos, vida, redes. Popayán: Envión Editores. 